\title{
On the use of open or closed traps in the capture of drosophilids
}

\author{
Leiza Penariol, Hermione Elly Melara de Campos Bicudo ${ }^{1}$ \& Lilian Madi-Ravazzi, ${ }^{1,2}$ \\ ${ }^{1}$ Laboratório de Genética, Ecologia e Evolução de Drosophila, Departamento de Biologia, \\ Instituto de Biociências, Letras e Ciências Exatas de São José do Rio Preto, \\ Universidade Estadual Paulista - UNESP, Rua Cristovão Colombo, 2265, \\ CEP 15054-000, São José do Rio Preto, SP, Brazil \\ ${ }^{2}$ Corresponding author: Lilian Madi-Ravazzi,e-mail: lilian@ibilce.unesp.br
}

PENARIOL, L., BICUDO, H.E.M.C. \& MADI-RAVAZZI, L. 2008. On the use of open or closed traps in the capture of drosophilids. Biota Neotrop. 8(2): http://www.biotaneotropica.org.br/v8n2/en/ abstract?article+bn00408022008.

\begin{abstract}
The use of open or closed traps in order to standardize the drosophilid collection is still a matter of discussion among researchers. In this paper, comparative data of drosophilid collections, using open and closed traps are presented. The collections were made monthly, during one year, in one fragment of a semidecidual forest located in the São Paulo State, Brazil. The efficiency of the traps was evaluated by the use of community descriptors: population abundance and richness and diversity of species. Closed traps were more efficient than the open ones in relation to the population abundance and the species richness, indicating their adequacy for standardization of drosophilid collection in studies of biodiversity and seasonality.

Keywords: capture traps, drosophilid, biodiversity, seasonality.
\end{abstract}

PENARIOL, L., BICUDO, H.E.M.C. \& MADI-RAVAZZI, L. 2008. Sobre o uso de armadilhas abertas ou fechadas na captura de drosofilídeos. Biota Neotrop. 8(2): http://www.biotaneotropica.org.br/v8n2/pt/ abstract?article+bn00408022008.

Resumo: Uma discussão ainda em pauta refere-se ao uso de armadilhas abertas ou fechadas na padronização das coletas de drosofilideos para alguns estudos específicos. Neste trabalho são apresentados dados comparativos das coletas de drosofilídeos utilizando armadilhas abertas e fechadas em um período de 12 meses, em um fragmento de floresta semidecidual, localizada no Estado de São Paulo, Brasil. A eficiência das armadilhas foi avaliada usando os seguintes descritores da comunidade: abundância populacional, riqueza e diversidade de espécies. As armadilhas fechadas foram mais eficientes em relação à abundância populacional e à riqueza de espécies. Os resultados indicam que as armadilhas fechadas constituem o tipo mais adequado para padronização de coleta de drosofilídeos, em estudos de biodiversidade e sazonalidade.

Palavras-chave: armadilhas de captura, drosofilídeos, biodiversidade, sazonalidade. 


\section{Introduction}

Flies of the genus Drosophila are adequate models for genetic, cytogenetic, molecular and ecological studies, intensively used in the last hundred years. Among ecological studies, researches on drosophilid communities have received increased attention. However, collecting methods are not standardized mainly in relation to the flies capture, including the kind of traps and baits used. Such variation makes difficult to compare data obtained in different studies.

In general, adult collecting methods are based on the capture of flies attracted to the baits. The capture may be active (using entomological net) or passive (using traps). Although these collecting methods do not allow estimating the population density, it allows estimating the availability of these organisms for accessing a certain resource (bait) (Southwood 1978). In addition to the population size, other factors affect the capture of the flies, such as the presence of other natural resources, which compete with the bait, the activity of the flies in the sampled period (Klaczko et al. 1983, Medeiros 2000), the part of the day in which the collection was done (Pavan et al. 1950, Belo \& Oliveira 1978) and the spatial distribution in the space (horizontal: Dobzhansky \& Pavan 1950, Burla et al. 1950, Pavan 1959, Medeiros 2000, Torres \& Madi-Ravazzi 2006 and vertical: Parsons 1975, Sene et al. 1981, Kratz et al. 1982, Tidon-Sklorz \& Sene 1992). Such factors may interfere in the estimative of Drosophila population parameters, sometimes hiding information or creating false standards.

Another problem is related to the bait which in general is a mixture of banana and fresh biological ferment (Saccharomyces cerevisiae), being influenced by environmental variables, which affect the fermentation process and, consequently, the bait attractiveness.

In summary, the mentioned variables influence the collection of the drosophilids, showing the need of standardized collecting methods aiming to minimize the errors and raising the possibility to compare different studies. One of the main discussions among drosophilid researchers is that related to the best trap for capturing representative samples to be used in studies about local biodiversity, richness and seasonality of the species (Medeiros \& Klaczko 1999).

The traps generally used for the collection of flies in the field are of two kinds, open or closed. The open traps have been the most used since the beginning of Drosophila studies. In them, the flies are free to enter and to leave the trap during the collection period. In the closed traps the attracted flies cannot leave them.

Medeiros \& Klaczko (2004) in a study of drosophilid fauna collected 13 Drosophila species not reported before in the São Paulo State. Differently of other authors they used closed traps and this may be one of the reasons for the efficiency. However, comparative studies involving the two kinds of traps were not carried out and then this hypothesis was not tested.

In the present study a comparison on richness, abundance and diversity of the species obtained using the two collection methods was carried out.

\section{Material and Methods}

The collections of flies were done in the Estação Ecológica de Paulo de Faria $\left(19^{\circ} 55^{\prime}\right.$ to $19^{\circ} 58^{\prime} \mathrm{S}$ and $49^{\circ} 31^{\prime}$ to $49^{\circ} 32^{\prime} \mathrm{W}$ ), a fragment of seasonal, semidecidual forest, with 435 hectares, in Paulo de Faria, São Paulo State, Brazil. The original vegetation of that region was a Mesophytic Semideciduous Forest now replaced by pasture (Project BRA/90/010; PROBIO 1998; IPT 2000). It is characterized by well pronounced dry season, with less than $15 \%$ of the annual precipitation (Barcha \& Arid 1971) and unpredictable rainfall at the beginning of the rainy season (Rossa-Feres \& Jim 2001).
The collections were carried monthly, from August 2004 to July 2005 , in two different areas from the woods, the edge and the interior. A track with $100 \mathrm{~m}$ of extension was established in each region, a collection point being demarcated at each ten meters (Figure 1). In each point, two traps, being an open (visitation, described in Torres \& Madi-Ravazzi 2006) and another closed (apprehension, described in Medeiros \& Klackzo 1999), were placed, at about $1.5 \mathrm{~m}$ from of the soil, hung on tree branches, and distant about two meters from each other (Figure 2a,b). The traps contained bait prepared with macerated banana and biological yeast (Saccharomyces cerevisiae) and remained in the collection places for a period of three days.

The flies were collected in the open traps using entomological net and transferred to glass tubes containing standard culture medium (banana-agar). The flies from the closed traps were transferred directly to the glass tubes. Afterwards, the specimens were transferred to bottles containing standard culture medium and transported to the laboratory. The identification of the specimens was as usual, by means of identification keys and, when needed, examining the aedeagus (Freire-Maia \& Pavan 1949, Kaneshiro 1969, Vilela 1983).

The efficiency of the sampling methodology was evaluated by the richness accumulation curves and by richness estimates obtained by the Abundance Coverage Estimator (ACE) and Incidence Coverage Estimator (ICE) in the Estimate Swin 7.0 program (Colwell 2004). These methods use data on abundance and richness to compute the number of species that occur in a studied area. The estimator ACE is influenced mostly by the presence of rare species, that is, the larger the number of rare species collected, the greater the probability that other species be collected with an increased sample effort. On the other hand, the estimator ICE is mainly based on low frequent species, that is, the larger the number of species captured in few collections, the greater the chance that all the species of the area have not been collected.

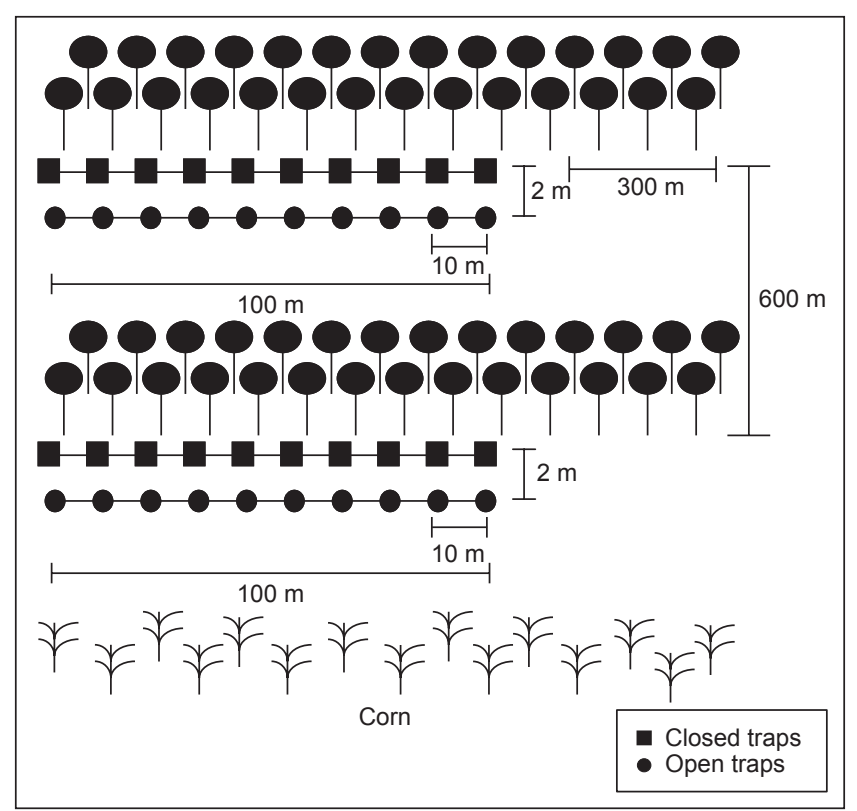

Figure 1. Design of the distribution of the open and closed traps used for drosophilid collections in the edge and interior areas of the forest fragment located in Paulo de Faria, São Paulo State, Brazil. Distance in meters.

Figura1. Desenho da distribuição das armadilhas abertas e fechadas usadas nas coletas de drosofilídeos nas áreas de borda e interior do fragmento florestal localizado em Paulo de Faria, Estado de São Paulo, Brasil. Distância em metros. 

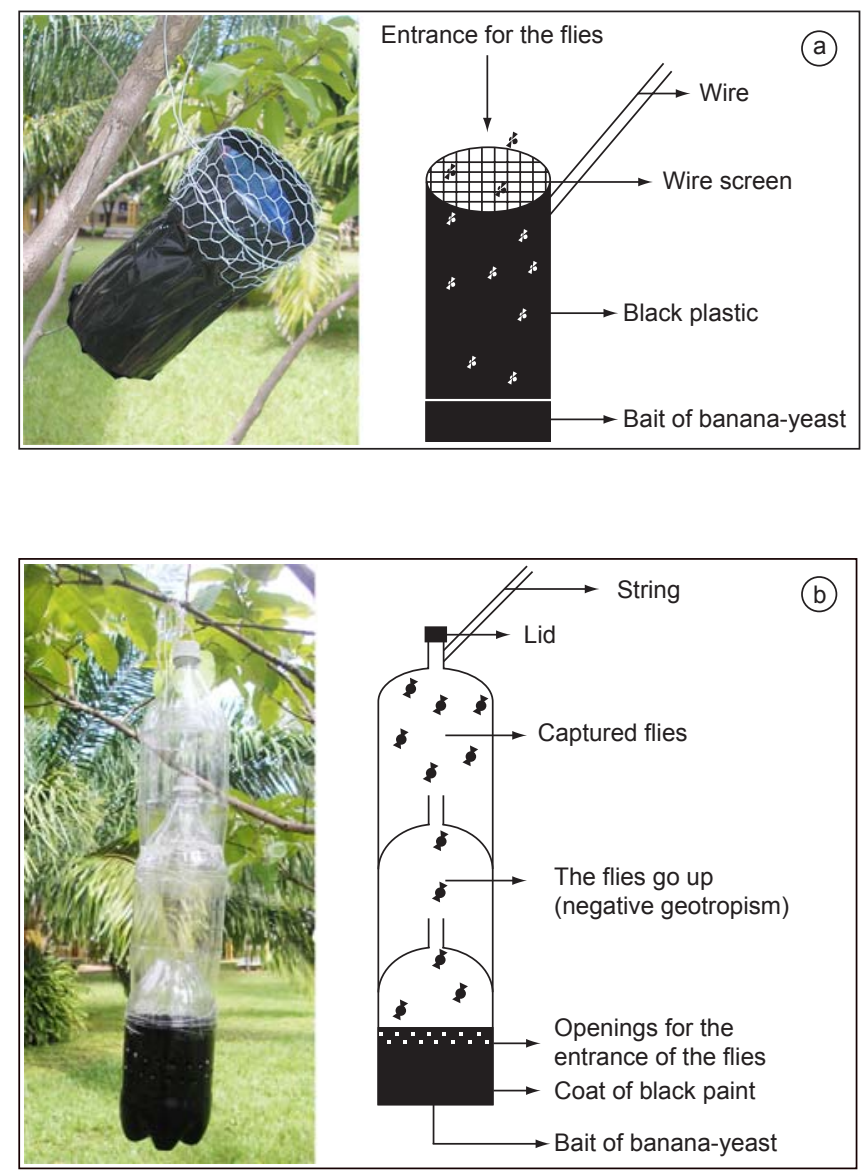

Figure 2. Images and drawings of the traps used for the capture of drosophilids. a) open trap; and b) closed trap.

Figura 2. Comparação da curva de acumulação da riqueza obtida pelos métodos ACE e ICE com a riqueza observada (OBS), para as armadilhas fechadas e abertas.
The drosophilid assemblage was evaluated separately in each collection method, joining data obtained in traps of the same kind located in the edge and interior area analyzed. The descriptors abundance, richness and diversity were analyzed. The species diversity was computed by the Shannon-Wiener index (Krebs 1999), which combines the two components of diversity, richness and equitability and considers mainly the rare species, an important characteristic because it is frequent in drosophilid assemblages. The comparison of the abundance values and of the diversity indices was accomplished by the application of the $t$ test pairing (Zar 1999), using the program Minitab version 12.22 program. The richness was evaluated by the Analysis of Dependence (ANADEP, Cordeiro 1987).

\section{Results and Discussion}

A total of 12.401 drosophilids, distributed in 18 species were collected, being 3.027 (24\%) in open traps (Table 1) and 9.374 $(76 \%)$ in closed traps (Table 2). The closed traps showed the same species captured in the open ones and two more, D. melanogaster and $D$. immigrans. In addition, the paired $t$ test indicated a greater efficiency of the closed trap regarding the number of collected flies $(t=11.51 ; \mathrm{p}<0.0005)$ and no significant difference between open and closed traps as to the diversity index $\left(H^{\prime}\right)(p=0.16)$.

The proximity of the curves produced by the richness estimators (ACE and ICE) to the real data obtained for open and closed traps indicates that both collection methods were efficient (Figure 3).

The ANADEP data, shown in Figure 4 indicate association between factors trap and species richness. The rare species (those with few captured individuals), such as D. ararama, D. immigrans and D. melanogaster showed closer association with the closed traps, while $D$. prosaltans and D. austrosaltans showed closer association with the open traps.

Medeiros \& Klaczko (2004) obtained, in closed traps, the surprising number of 125 species, from which 72 had been previously identified as described species and the majority of the 53 unidentified species were probably undescribed. Thirteen species were absent from the previous species list for São Paulo State (Tidon-Sklorz \& Sene 1999).

Table 1. Total abundance of the species collected in open traps. Z. = Zaprionus; $S .=$ Scaptodrosophila and D. = Drosophila .

Tabela 1. Abundâcia total das espécies coletadas nas armadilhas abertas. Z. = Zaprionus; S. = Scaptodrosophila and D. = Drosophila .

\begin{tabular}{|c|c|c|c|c|c|c|c|c|c|c|c|c|c|c|c|c|c|c|c|c|c|c|}
\hline \multirow[t]{2}{*}{ Species } & \multirow[b]{2}{*}{ Code } & \multicolumn{21}{|c|}{ Open traps } \\
\hline & & T1 & T2 & T2 & T4 & T5 & T6 & T7 & $\mathrm{T8}$ & T9 & T10 & T11 & T12 & T13 & T14 & T15 & T16 & T17 & T18 & T19 & T20 & Total \\
\hline Z. indianus & zap & 26 & 8 & 20 & 63 & 44 & 10 & 8 & 2 & 14 & 28 & 4 & 0 & 0 & 8 & 1 & 4 & 0 & 4 & 0 & 2 & 246 \\
\hline S. latifasciaeformis & scp & 2 & 5 & 3 & 46 & 9 & 3 & 0 & 0 & 36 & 13 & 1 & 1 & 0 & 0 & 2 & 1 & 1 & 0 & 0 & 0 & 123 \\
\hline D. simulans & sim & 63 & 46 & 65 & 89 & 97 & 59 & 39 & 88 & 72 & 62 & 21 & 8 & 19 & 17 & 32 & 31 & 31 & 15 & 23 & 17 & 894 \\
\hline D. malerkotliana & mal & 2 & 6 & 21 & 16 & 16 & 14 & 10 & 10 & 18 & 28 & 1 & 20 & 14 & 4 & 21 & 17 & 16 & 25 & 1 & 0 & 260 \\
\hline D. polymorpha & pol & 4 & 6 & 8 & 21 & 4 & 6 & 4 & 6 & 16 & 32 & 2 & 10 & 7 & 8 & 0 & 7 & 1 & 1 & 3 & 7 & 153 \\
\hline D. nebulosa & neb & 13 & 1 & 3 & 2 & 6 & 0 & 0 & 1 & 4 & 0 & 1 & 4 & 0 & 1 & 2 & 1 & 9 & 2 & 1 & 4 & 55 \\
\hline D. guarani & gua & 0 & 0 & 0 & 2 & 0 & 0 & 0 & 0 & 0 & 0 & 0 & 1 & 0 & 0 & 0 & 0 & 0 & 0 & 0 & 0 & 3 \\
\hline D. mediopunctata & mdp & 0 & 0 & 0 & 2 & 0 & 0 & 0 & 0 & 0 & 0 & 0 & 0 & 0 & 0 & 0 & 0 & 0 & 0 & 0 & 0 & 2 \\
\hline D. mediostriata & mdt & 0 & 0 & 0 & 0 & 0 & 0 & 0 & 0 & 0 & 0 & 0 & 1 & 0 & 0 & 0 & 0 & 0 & 0 & 0 & 0 & 1 \\
\hline D. ararama & ara & 0 & 0 & 0 & 0 & 0 & 0 & 0 & 0 & 0 & 0 & 0 & 0 & 0 & 1 & 0 & 0 & 0 & 0 & 0 & 0 & 1 \\
\hline D. willistoni & wil & 44 & 26 & 40 & 1 & 17 & 7 & 21 & 29 & 16 & 7 & 31 & 48 & 82 & 14 & 67 & 87 & 30 & 34 & 48 & 66 & 715 \\
\hline D. mercatorum & mer & 5 & 0 & 3 & 3 & 13 & 1 & 5 & 1 & 5 & 3 & 3 & 1 & 2 & 2 & 0 & 1 & 4 & 0 & 0 & 0 & 52 \\
\hline D. paranaensis & par & 4 & 7 & 7 & 2 & 2 & 4 & 7 & 6 & 1 & 6 & 1 & 1 & 4 & 3 & 1 & 2 & 2 & 2 & 1 & 0 & 63 \\
\hline D. sturtevanti & stu & 32 & 14 & 10 & 19 & 36 & 21 & 29 & 23 & 20 & 16 & 14 & 13 & 5 & 23 & 13 & 7 & 12 & 21 & 12 & 12 & 352 \\
\hline D. prosaltans & pro & 0 & 2 & 1 & 11 & 3 & 4 & 1 & 0 & 0 & 1 & 4 & 6 & 2 & 1 & 2 & 5 & 7 & 4 & 0 & 3 & 57 \\
\hline D. austrosaltans & aus & 2 & 1 & 0 & 3 & 2 & 0 & 5 & 1 & 2 & 2 & 4 & 4 & 1 & 1 & 1 & 6 & 11 & 1 & 0 & 3 & 50 \\
\hline Total & & 197 & 122 & 181 & 280 & 249 & 129 & 129 & 167 & 204 & 198 & 87 & 118 & 136 & 83 & 142 & 169 & 124 & 109 & 89 & 114 & 3027 \\
\hline
\end{tabular}


Table 2. Total abundance of the species collected in closed traps. Z. = Zaprionus; S. = Scaptodrosophila and D. = Drosophila.

Tabela 2. Abundância total das espécies coletadas nas armadilhas fechadas. Z. = Zaprionus; S. = Scaptodrosophila and D. = Drosophila .

\begin{tabular}{|c|c|c|c|c|c|c|c|c|c|c|c|c|c|c|c|c|c|c|c|c|c|c|}
\hline \multirow[t]{2}{*}{ Species } & \multicolumn{22}{|c|}{ Closed Traps } \\
\hline & Code & T1 & T2 & T3 & T4 & T5 & T6 & T7 & T8 & T9 & T10 ] & T11 & T12 & T13 & T14 & T15 & T16 & T17 & T18 & T19 & T20 & Total \\
\hline z. indianus & zap & 76 & 102 & 84 & 69 & 111 & 82 & 91 & 102 & 85 & 82 & 3 & 5 & 1 & 7 & 19 & 1 & 11 & 4 & 2 & 11 & 948 \\
\hline . latifasciaeformis & $\mathrm{scp}$ & 8 & 11 & 17 & 6 & 4 & 13 & 3 & 24 & 5 & 3 & 10 & 8 & 0 & 5 & 0 & 0 & 0 & 7 & 0 & 0 & 124 \\
\hline D. simulans & $\operatorname{sim}$ & 329 & 240 & 154 & 232 & 383 & 305 & 281 & 343 & 241 & 2611 & 180 & 157 & 98 & 27 & 75 & 106 & 80 & 89 & 48 & 93 & 3722 \\
\hline D. malerkotliana & mal & 38 & 14 & 10 & 13 & 20 & 24 & 27 & 12 & 10 & 11 & 17 & 26 & 21 & 40 & 10 & 33 & 20 & 8 & 33 & 16 & 403 \\
\hline D. melano & mel & 0 & 0 & 0 & 0 & 0 & 1 & 0 & 0 & 0 & 0 & 1 & 0 & 0 & 0 & 0 & 0 & 0 & 0 & 0 & 0 & 2 \\
\hline D. polym & po & 21 & 18 & 12 & 16 & 24 & 18 & 25 & 19 & 9 & 17 & 10 & 7 & 10 & 16 & 15 & 12 & 30 & 81 & 22 & 7 & 389 \\
\hline D. nebulosa & & 10 & 18 & 19 & 6 & 17 & 15 & 17 & 25 & 10 & 14 & 16 & 15 & 11 & 17 & 17 & 19 & 52 & 63 & 43 & 17 & 421 \\
\hline D. guarani & & 0 & 0 & 0 & 0 & 1 & 0 & 0 & 1 & 0 & 3 & 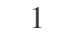 & 0 & 0 & 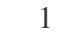 & 2 & 0 & 0 & 0 & 0 & 0 & 12 \\
\hline tatc & $\mathrm{p}$ & 0 & 1 & 0 & 2 & 0 & 0 & 1 & 0 & 2 & 0 & 8 & 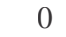 & 0 & 0 & 1 & 0 & 0 & 0 & 0 & 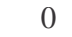 & 7 \\
\hline medios & mdt & 0 & 0 & 0 & 0 & 0 & 0 & 0 & 0 & 0 & 0 & 0 & 2 & 1 & 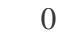 & 0 & 0 & 0 & 1 & 1 & 0 & 5 \\
\hline D. immigr & img & 0 & 0 & 0 & 0 & 0 & 0 & 2 & 0 & 0 & 0 & 0 & 0 & 0 & 0 & 0 & 0 & 0 & 0 & 0 & 0 & 2 \\
\hline D. ararama & ara & 1 & 1 & 1 & 0 & 0 & 1 & 1 & 5 & 2 & 0 & 0 & 3 & 0 & 3 & 0 & 1 & 0 & 0 & 0 & 3 & 22 \\
\hline D. willistoni & wi & 49 & 42 & 48 & 42 & 18 & 52 & 34 & 19 & 33 & 561 & 143 & 101 & 103 & 167 & 121 & 95 & 139 & 376 & 209 & 192 & 2039 \\
\hline D. mercatorum & mer & 46 & 49 & 40 & 47 & 10 & 16 & 16 & 20 & 13 & 0 & 5 & 5 & 12 & 3 & 4 & 9 & 4 & 6 & 4 & 8 & 317 \\
\hline D. paranaensis & par & 84 & 63 & 50 & 38 & 21 & 16 & 5 & 10 & 2 & 10 & 4 & 4 & 18 & 4 & 4 & 8 & 5 & 5 & 4 & 6 & 361 \\
\hline D. sturtevanti & stu & 16 & 30 & 54 & 23 & 21 & 38 & 47 & 36 & 42 & 39 & 12 & 17 & 25 & 8 & 12 & 6 & 17 & 25 & 16 & 38 & 522 \\
\hline D. prosaltans & ro & 0 & 1 & 0 & 0 & 2 & 1 & 1 & 5 & 0 & 1 & 1 & 2 & 2 & 5 & 2 & 1 & 6 & 2 & 4 & 1 & 37 \\
\hline D. austrosaltans & aus & 2 & 1 & 3 & 0 & 1 & 0 & 0 & 0 & 1 & 3 & 3 & 3 & 3 & 1 & 2 & 3 & 6 & 2 & 4 & 3 & 41 \\
\hline Total & & 680 & 591 & 492 & 494 & 633 & 582 & 551 & 621 & 455 & 5004 & 406 & 358 & 305 & 304 & 284 & 294 & 370 & 669 & 390 & 395 & 9374 \\
\hline
\end{tabular}
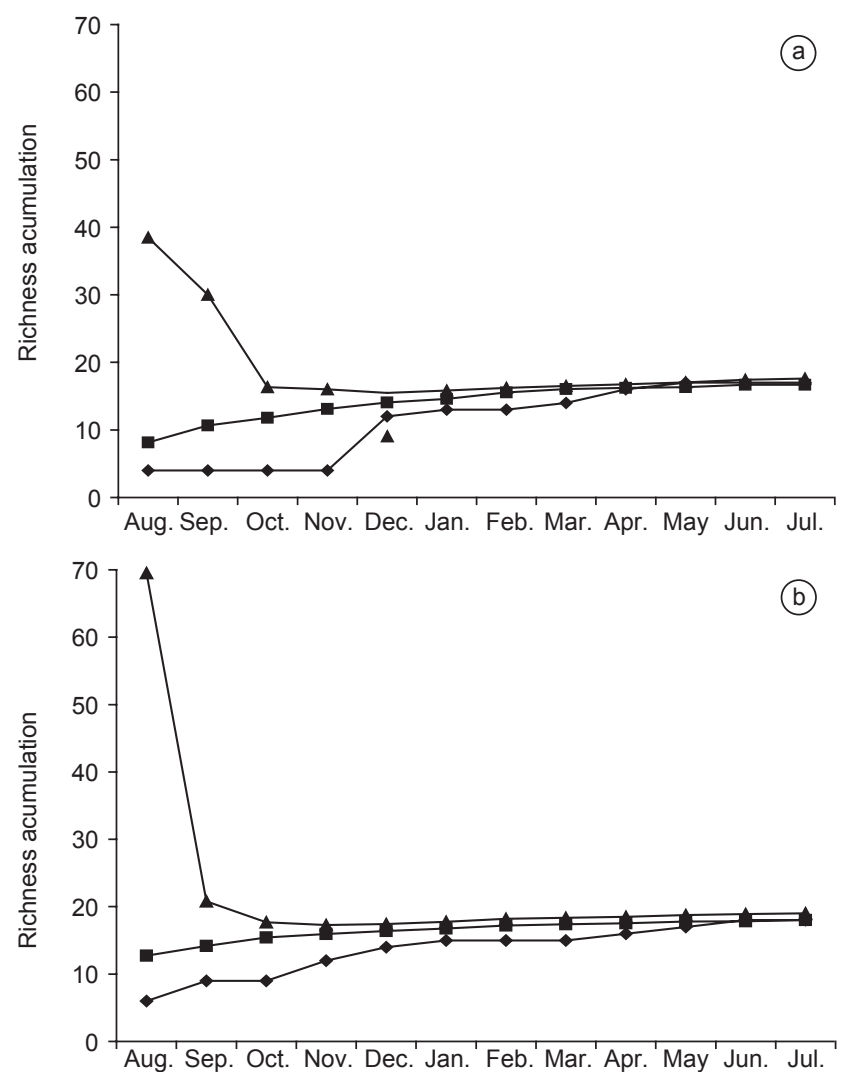

\section{$\rightarrow \mathrm{OBS} \rightarrow \mathrm{ACE} \rightarrow \mathrm{ICE}$}

Figure 3. Comparison of the richness accumulation curves obtained by the methods ACE and ICE with the observed richness (OBS), for open and closed traps. a) open trap; and b) closed trap.

Figura 3. Comparação das curvas de acumulação da riqueza obtidas pelos métodos ACE e ICE com a riqueza observada (OBS), para as armadilhas fechadas e abertas.

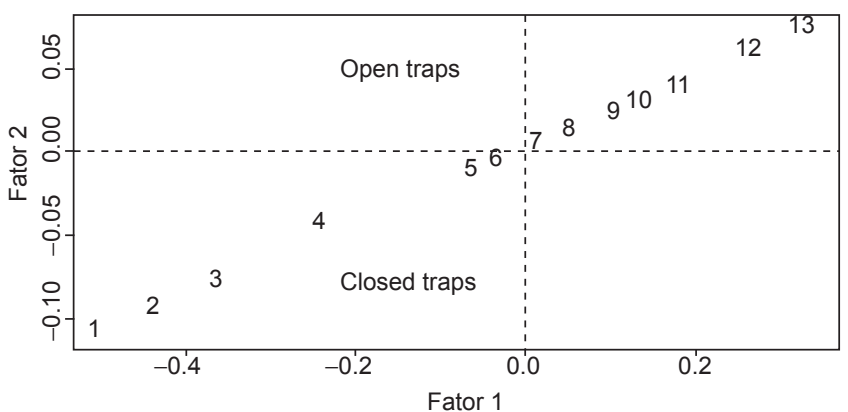

Figure 4. Analysis of dependence (ANADEP), relating the open and closed traps with the richness of the species 1) Drosophila prosaltans, 2) D. austrosaltans, 3) Scaptodrosophila latifasciaeformis, 4) D. stutervanti e D. malerkotliana, 5) D. polymorpha, 6) D. willistoni, 7) D. mediopunctata, 8) D. simulans, D. guarani e Zaprionus indianus, 9) D. mediostriata, 10) D. mercatorum e D. paranaensis, 11) D. nebulosa, 12) D. ararama, and 13) D. immigrans e D. melanogaster.

Figure 4. Análise de dependência (ANADEP), relacionando as armadilhas fechadas e abertas com a riqueza das espécies. D. prosaltans (pro), D. austrosaltans (aus), S. latifasciaeformis (scp), D. sturtevanti (stu), D. malerkotliana (mal), D. polymorpha (pol), D. willistoni (wil), D. mediopunctata (mdp), Z. indianus (zap), D. guarani (gua), D. simulans (sim), D. mediostriata (mdt), D. paranaensis (par), D. mercatorum (mer), D. nebulosa (neb), D. ararama (ara), D. imigrans (img) and D. melanogaster (mel).

The difference of richness between the mentioned data and the present study may be due mainly to the size of the collection area and to details of the collection method such as the location of the traps in a higher position from the soil than that we used. In addition, studies involving other organisms have indicated that, in the area used in the present study, the biological diversity is lower (Santos et al. 2007) and the environment exhibits higher degree of deforestation than other areas from the State of São Paulo (Ranga \& Stranghetti 1998).

Other studies involving monthly collections performed in the Ecological Station of Paulo de Faria since 2003, using exclusively 
open traps, showed greater abundance and richness than those obtained in the closed traps, in the present study (Amaral 2004, Penariol 2007). Our hypothesis to explain these differences is based on climatic changes occurred in the region, such as less characterized dry and humid seasons and environmental stress due to change in the type of plantation around of the wood (from corn to pasture). We also cannot discard the possibility of interference caused by the introduction of the drosophilid Zaprionus indianus, in the area, in the last years.

In resume, the present study showed that the closed traps are more efficient than the open ones, regarding the abundance and richness of species, which are the basic features to characterize an assemblage of drosophilids. The closed traps also offer practical advantages as to the simplicity of manipulation and cleaning, protection against rain and predator attacks and the possibility of complete preparation (including the baits) before transport of the traps to the collection places. Taken together, the present observations indicate the use of this kind of collection traps for studies on Drosophila species biodiversity and seasonality, in wood regions and for ecological studies such as the edge effect.

\section{Acknowledgements}

Thanks are due to Dr Hermes F. de Medeiros for providing the model of the closed traps used here, to Dr Antônio Cordeiro for help in the statistical analyses, to Dr Denise Rossa-Feres for critical review of this manuscript and to FAPESP (04/04559-3) and CAPES for fellowships given to L. Penariol.

\section{References}

AMARAL, O. 2004. Biodiversidade e sazonalidade de drosofilídeos na Estação Ecológica de Paulo de Faria,SP. Dissertação de Mestrado, Instituto de Biociência, Letras e Ciências Exatas, Universidade Estadual Paulista - UNESP, São José do Rio Preto, São Paulo.

BARCHA, S. F. \& ARID, F. M. 1971. Estudo da evapotranspiração na região norte-ocidental do Estado de São Paulo. Ver. Cienc. Facul. Cienc. e Letras 1:94-122.

BELO, M. \& OLIVEIRA-FILHO, J.J. 1978. Espécies domésticas de Drosophila. V. Influências de fatores ambientais no número de indivíduos capturados. Rev. Brasil. Biol. 36:903-909.

BURla, H., CUNHA, A.B., CAVAlCANTI, A.G.L., PAVAN, C. \& DOBZHANSKY, T. 1950. Population density and dispersal rates in Brazilian Drosophila willistoni. Ecology 31:393-404.

COLWELL, R.K. 2004. EstimateS 7.0: Statistical estimation of species richness and shared species from samples. User's guide and application. http://viceroy.eeb.uconn.edu/estimates (último acesso em 08/2005).

CORDEIRO, J.A. 1987. Analysis of Dependency. Relatório Técnico 48/87, ME-UNICAMP, Campinas.

DOBZHANSKY, T. \& PAVAN, C. 1950. Local and seasonal variations in relative frequencies of species of Drosophila in Brazil. J. Anim. Ecol. 19:1-14.

FREIRE-MAIA, N. \& PAVAN, C. 1949. Introdução ao estudo da Drosophila. Cultus. 1:1-171.

IPT (Instituto de Pesquisas Tecnológicas do Estado de São Paulo) 2000. Diagnóstico da situação atual dos recursos hídricos e estabelecimento de diretrizes técnicas para a elaboração do Plano da Bacia São José dos Dourados, relatório no 40675, (minuta CD-Rom).

KANESHIRO, K.Y. 1969. A study of the relationships of Hawaiian Drosophila species based on external male genitalia. Univ. Texas Pub. 6918:55-70.

KLACZKO, L.B., POWELL, J.R. \& TAYLOR, C.E. 1983. Drosophila baits and yeasts: species attracted. Oecologia 59:411-413.

KRATZ, F.L., PINTO, L.G., BRANDÃO, D. \& FARIA, L.G. 1982. Altura de vôo e o padrão de distribuição espacial em Drosophila. Cienc. Cult. 34:203-209.
KREBS, C.J. 1999. Ecological methodology. Addison Wesley Educational Publishes, Menlo Park.

MEDEIROS, H.F. 2000. Assembléias de espécies de Drosophila (Díptera: Drosophilidade) e efeitos de cursos d'água sobre suas distribuições em duas matas de São Paulo. Dissertação de Mestrado, Instituto de Biologia, UNICAMP, Campinas.

MEDEIROS, H.F. \& KLACZKO, L.B. 1999. A weakly biased Drosophila trap. Dros. Inf. Serv. 82:100-102.

MEDEIROS, H.F. \& KLACZKO, L.B. 2004. How many species of Drosophila (Diptera: Drosophilidae) remain to be described in the forests of Sao Paulo, Brazil Species lists of three forest remnants. Biota Neotrop. 4(1): http://www.biotaneotropica.org.br/v4n1/pt/abstract?article+BN01604 012004.

PARSON, P.A. 1975. The effect of temperature and humidity on the distribuition patterns of Drosophila inornata in Victoria, Australia. Environ. Entomol. 41:961-964.

PAVAN, C. 1959. Relações entre populações naturais de Drosophila e o meio ambiente. Bol. Fac. Filos. Cienc. e Letras Univ. S. Paulo (86), Biologia Geral 11:7-81.

PAVAN, C., DOBZHANSKY, T. \& BURLA, H. 1950. Diurnal behavior of some neotropical species of Drosophila. Ecology 31:36-43.

PENARIOL, L. 2007. Assembléia de drosofilídeos na borda e no interior de um fragmento de floresta estacional no noroeste do Estado de São Paulo. Dissertação de Mestrado, Instituto de Biociência, Letras e Ciências Exatas, Universidade Estadual Paulista - UNESP, São José do Rio Preto, São Paulo.

RANGA, N.T. \& STRANGHETTI, V. 1998. Levantamento florístico das espécies vasculares da floresta estacional mesófila semidecídua da Estação Ecológica de Paulo de Faria. Rev. Bras. Bot. 21:295-304.

ROSSA-FERES, D.C. \& JIM, J. 2001. Similaridade no sítio de vocalização em uma comunidade de anfíbios anuros na região noroeste do estado de São Paulo, Brasil. Rev. Bras. Zool. 18(2):439-454.

SANTOS, T.G., ROSSA-FERES, D.C. \& CASATTI, L. 2007. Diversidade e distribuição espaço-temporal de anuros em região com pronunciada estação seca no sudeste do Brasil Iheringia, Ser. Zool. 97:37-49.

SECRETARIA DO MEIO AMBIENTE DO ESTADO DE SÃO PAULO, PROJETO BRA/90/010. 1995. Os ecossistemas brasileiros e os principais macrovetores de desenvolvimento: subsídios ao planejamento da gestão ambiental. Ministério do Meio Ambiente, Brasília.

SECRETARIA DO MEIO AMBIENTE DO ESTADO DE SÃO PAULO, PROBIO. 1998. Áreas de domínio do cerrado no Estado de São Paulo. Imprensa Oficial da Secretaria do Meio Ambiente de São Paulo, São Paulo.

SENE, F.M., PEREIRA, M.A.Q.R., VILELA, C.R. \& BIZZO, N.M.V. 1981. Influence of different ways to set baits for collection of Drosophila flies in three natural environments. Dros. Inf. Serv. 56:118-121.

SOUTHWOOD, T.R.E. 1978. Ecological methods with particular reference to the study of insect populations. Chapman and Hal, London.

TIDON-SKLORZ, R. \& SENE, F.M. 1992. Vertical and temporal distribution of Drosophila (Diptera: Drosophilidae) species in a wooded area in the state of Sao Paulo, Brazil. Rev. Bras. Biol. 52:311-317.

TIDON-SKLORZ, R. \& SENE, F.M. 1999. Drosophila. In Biodiversidade do Estado de São Paulo, Brasil: síntese do conhecimento ao final do século XX (C.R.F. Brandão \& E.M. Cancello, eds). 5 ed. Invertebrados terrestres, FAPESP, São Paulo.

TORRES, F.R. \& MADI-RAVAZZI, L. 2006. Seasonal variation in natural populations of Drosophila spp. (Diptera) in two woodland in the state of São Paulo, Brazil. Iheringia, Ser. Zool. 96(4):437-444.

ZAR, J. H. 1999. Biostatistical Analysis. Prentice Hall, New Jersey.

Data Received 22/10/07 Revised 25/03/08 Accepted 01/04/08 